\title{
Engineering geologic evaluation of overcompacted claystone, new metro line, Budapest
}

Ildikó Barsi, Péter Görög, Ákos Török

Department of Construction Materials and Engineering Geology

Budapest University of Technology and Economics, Budapest

\begin{abstract}
The Oligocene clay units in the Budapest area along the new metro (subway) line show different properties than most others. They are denser and of greater strength than most of the unconsolidated ones. This paper provides an overview of their engineering geologic properties using nearly 4700 physical parameter data. These data were obtained from cores representing sampling intervals of the Kiscell Clay, on the Buda side of the Danube River. Seventeen engineering geologic parameters were used in the description of the clay. The parameter analyses show that the clay behaves as a soft rock rather than a soil.
\end{abstract}

Keywords: engineering geology, overcompacted clay, laboratory testing, statistical analysis

\section{Introduction}

The Oligocene Kiscell Clay is a widespread formation that occurs in the surroundings of Budapest and is often exposed in foundation pits. Previous studies concentrated on the physical properties of the clay and dealt with landslides (Paál 1976; Németh 1980). Extensive studies were carried out in relation to large construction projects, as well as the necessary laboratory tests (Horváth et al. 2000; Paál 2001). The earlier publications listed above clearly demonstrate that the Kiscell Clay is not a uniform sediment, and that its properties change from place to place. Statistical analyses of soil mechanical parameters and engineering geologic properties of the Kiscell Clay occurrences in parts of Buda had previously been made (Görög 2007a, b), but additional new datasets require

Addresses: I. Barsi, P. Görög, Á. Török: H-1111 Budapest, Múegyetem rkp. 3, Hungary, e-mail: torokakos@mail.bme.hu

Received: June 27, 2012; accepted: November 28, 2012 
further analyses. The present paper analyses the new dataset in comparison with previous results, as new core data and laboratory analyses have become available along Metro Line 4, which is currently under construction.

\section{Engineering geologic settings}

History of the construction of Metro Line 4

There have been many plans for the design of the metro (subway) network of Budapest in the past century. Most of these designs consider a line that connects the southern Buda side with the central eastern Pest side (Zugló). The plans were unanimous that the new line (called Line 4) was to pass through Móricz Zsigmond Square (a centrally located square on the Buda side) and should end at Bosnyák Square (a centrally located square in the eastern part of Pest). The new line required junctions with the already existing Lines 2 and 3. Meanwhile there had been discussions about the alignment on the Buda side, whether it should follow Fehérvári Street to Budafok, or should pass Etele Square and terminate at Budaörs (www1).

Preparations for construction began in the early 1970s, when the previous plans and designs were re-evaluated. This 30-year-long process began in 1972, when the Development Plan of Budapest declared that the new so-called Line 4 should be the South Buda-Rákospalota line. In 1974 the Hungarian Technical Development Committee finalized the alignment and outlined the construction technology. Two years later the Ministerial Board made a decision (no. 3034/1976) and declared that the beginning of the construction would be in 1978. Due to financial and political uncertainties and legal cases, the contract was only signed 25 years later in 2003. The construction of the tunnel and stations only began in 2006 (www2).

\section{The alignment of Metro Line 4}

The new metro line (Line 4) is divides into two sections. The first one includes a $7.3 \mathrm{~km}$-long double tunnel system between Kelenföld Railway Station and Keleti (East) Railway Station. Along this part 10 stations are planned. The stations on the Buda side are Kelenföld Railway Station, Tétényi Street, Bocskai Street, Móricz Zs. Square, and St. Gellért Square (Fig. 1). The second section, which is still in the planning stage, includes an additional 4 kilometers from Keleti Railway Station to Bocskai Street. Extension plans for the line consider a line to Budaörs or to Rákospalota.

The line is below ground due to the need to cross the Danube and to intersect previously existing metro lines and rail connections. No horizontal sections occur; the inclination of the most gentle slope is $3.0 \%$, while the steepest one is $36.3 \%$. The deepest point is located at St. Gellért square (73.75 $\mathrm{m}$ asl), while the highest point is at Kelenföld Station at an altitude of $96.27 \mathrm{~m}$ asl (www2). 


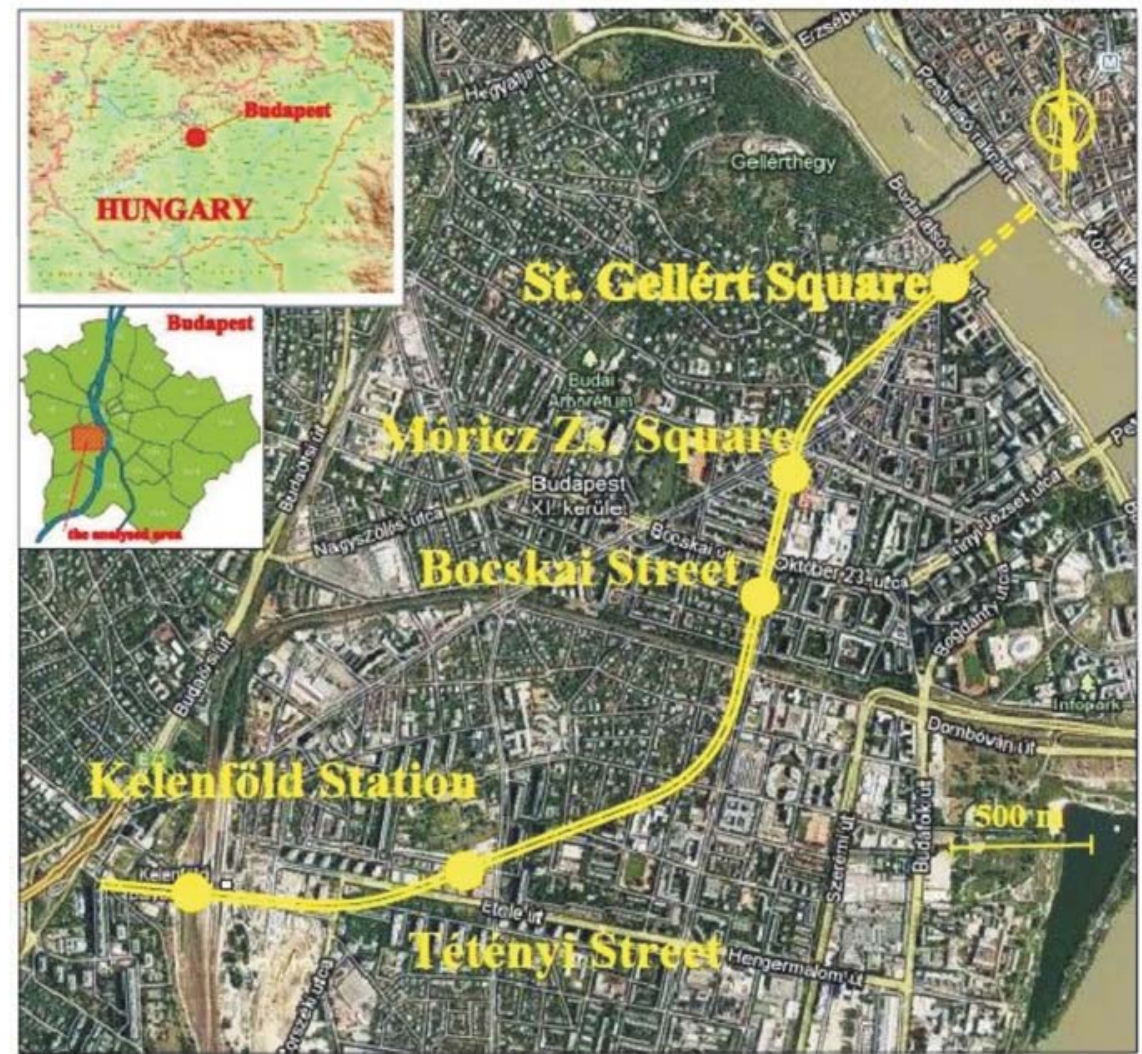

Fig. 1

The alignment of Metro Line 4 on the Buda side

\section{Geologic build-up of the Buda side}

Although the geology of the Budapest area is very complex and shows several structural geologic events, the metro line on the Buda side dissects fairly homogeneous formations until St. Gellért Square Station. The tunnels, the stations, and the service tunnels are mostly located within Oligocene clay formations (Geovil 2005). The most widespread one is the Kiscell Clay Formation. This formation is divided into three, engineering geologically differing, rock types: the upper "weathered" zone, the middle "expanded" zone and the lower "intact" Kiscell Clay. Most of the tunnels and most of the stations are cut into the expanded and intact clays (Horváth et al. 2000). At St. Gellért Square and at the Danube crossing, other formations are also present. A tectonic contact between the Kiscell Clay and Tard Clay Formations was recorded in the previous engineering geologic analyses (Geovil 2005). In the foundation pit of St. Gellért Square Station very steeply-tilting bedding planes of Kiscell Clay were observed. 
The oldest formation along the line is represented by Late Triassic dolomite, that was encountered in cores cut at St. Gellért Square and in the riverbed of the Danube. These uplifted Triassic karstic blocks beneath the river were also documented by using geophysical methods (Tóth et al. 2003).

Within the study area the Kiscell Clay and Tard Clay are covered by Quaternary deposits. These are partly associated with smaller streams from hill slopes, and partly with the Danube. The lithology of these deposits is dominated by clay, silt, and sandy clay, while close to the Danube sandy gravel prevails. Anthropogenic landfill is also very important and was encountered all along the line. Its thickness shows significant variations. At Lágymányosi Street-Bartók B. Street it is $5.2 \mathrm{~m}$ thick, while at Bertalan L. Street-Bartók B. Street it is reduced to $2.8 \mathrm{~m}$. Beneath the anthropogenic landfill, clay, silt, and silty sand are most common, with a thickness of 7-13 m, according to Farkas et al. (1999).

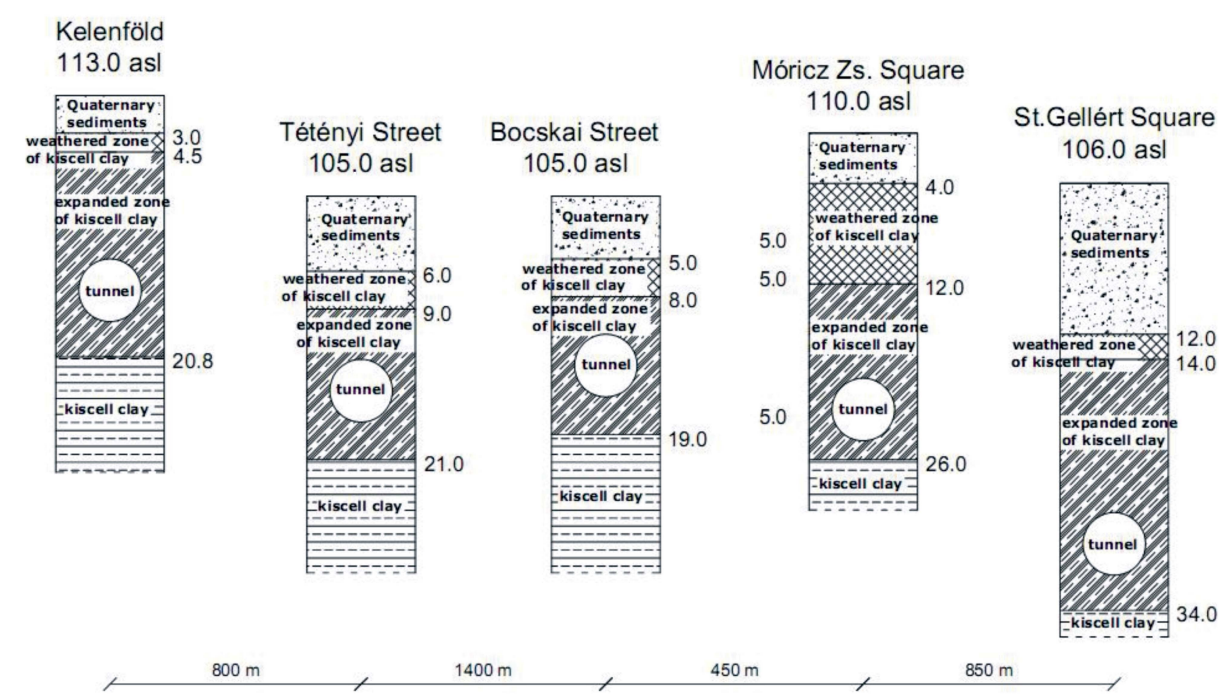

Fig. 2

Simplified stratigraphic columns for 5 stations

\section{Dataset}

Between 1966 and 1980 more than 500 cores with a total length of approx. $20 \mathrm{~km}$ were cut for the evaluation of the new metro line. The depths of these corings were between 30-200 m (Hegyi et al. 1981). In addition to these, new sets of exploratory cores were cut in the 1990s (Geovil 2005).

For the engineering geologic evaluation of overcompacted claystone, 41 cores were selected. These cores were cut between 1977 and 1999 using double or triplecasing techniques. The location of the corings and their codes are shown on a 


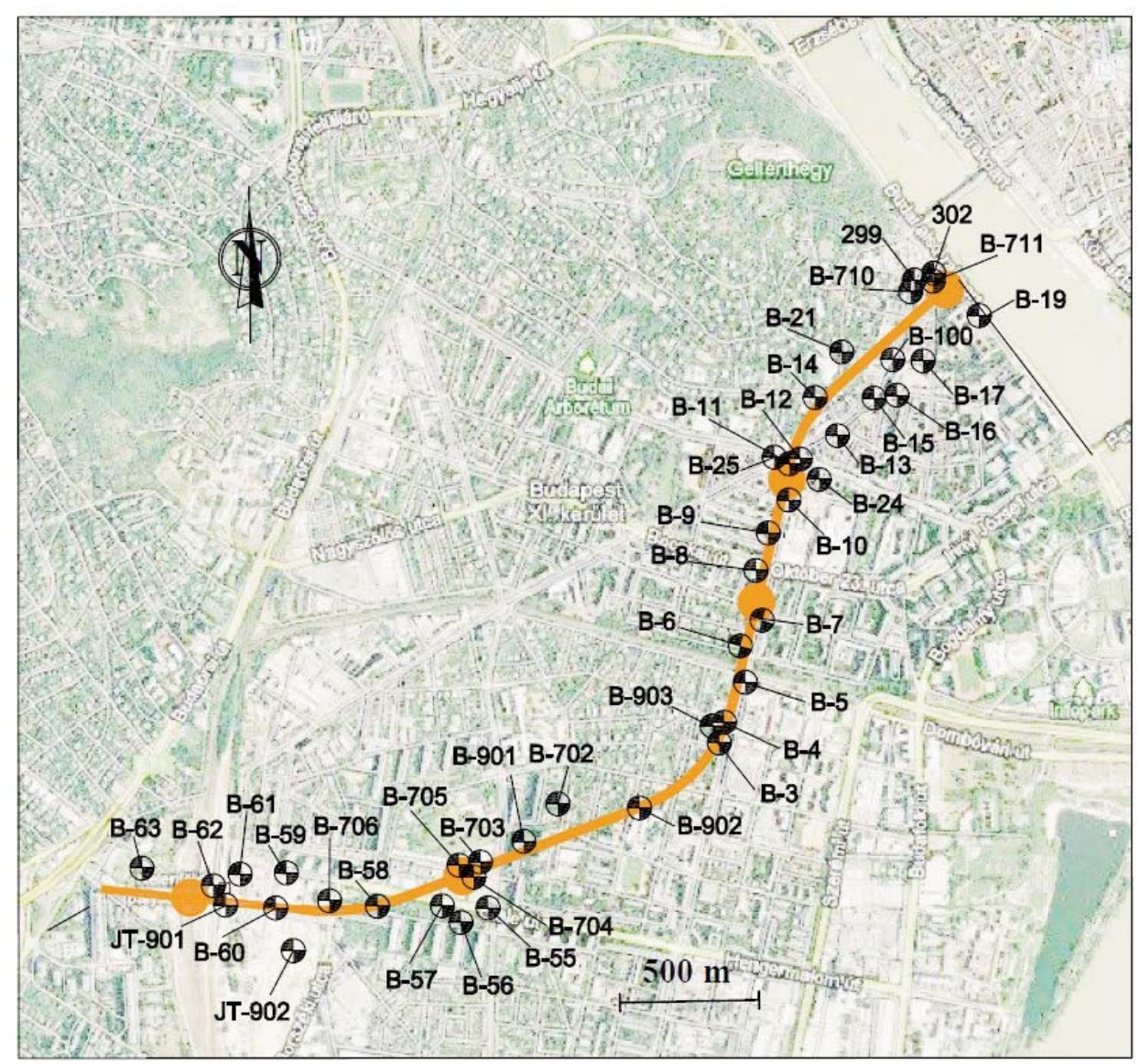

Fig. 3

Location of studied cores

simplified map (Fig. 3). The depth of the studied intervals and the number of samples from each core location are given in Table 1.

Altogether 482 sampling intervals were selected from the grey Kiscell Clay. The samples from the weathered upper zone of the clay were not included in the present study. The sampling depths were between 5.5 and $60 \mathrm{~m}$, although $90 \%$ of the samples were from depths greater than $12 \mathrm{~m}$ below surface.

From the selected 482 intervals, nearly 4700 parameters were used for the engineering geologic evaluation. These parameters include water content $(w)$, plasticity limit $\left(\mathrm{w}_{\mathrm{p}}\right)$, liquid limit $\left(\mathrm{w}_{\mathrm{L}}\right)$, plasticity index $\left(\mathrm{I}_{\mathrm{p}}\right)$, consistency index $\left(\mathrm{I}_{\mathrm{c}}\right)$, wet density $\left(\rho_{\mathrm{n}}\right)$, dry density $\left(\rho_{\mathrm{d}}\right)$, water-saturated density $\left(\rho_{\mathrm{t}}\right)$, void ratio $(\mathrm{e})$, porosity $(\mathrm{n})$, ratio of solid particles $(\mathrm{s})$, degree of saturation $\left(\mathrm{S}_{\mathrm{r}}\right)$, cohesion $(\mathrm{c})$, angle of friction $(\varphi)$, coefficient of compressibility (Es), modulus of elasticity (E), and 
Table 1

Data set with code of corings, depth profiles and no. of samples

\begin{tabular}{|l|c|c|c|c|}
\hline \multirow{2}{*}{ Place of borehole } & \multirow{2}{*}{$\begin{array}{c}\text { Sign of } \\
\text { borehole }\end{array}$} & \multicolumn{2}{|c|}{$\begin{array}{c}\text { Depth of samples } \\
\text { [m] }\end{array}$} & $\begin{array}{c}\text { No. of } \\
\text { samples }\end{array}$ \\
\cline { 3 - 4 } & & from & to & \\
\hline St. Gellért Square & B-19 & 28.8 & 58.8 & 7 \\
\hline St. Gellért Square & 299 & 15.0 & 25.0 & 5 \\
\hline St. Gellért Square & B710 & 13.0 & 34.0 & 9 \\
\hline St. Gellért Square & B17 & 11.4 & 48.0 & 14 \\
\hline St. Gellért Square & B100 & 10.6 & 54.3 & 25 \\
\hline St. Gellért Square & B-21 & 20.5 & 60.0 & 10 \\
\hline St. Gellért Square & B-16 & 15.0 & 49.5 & 15 \\
\hline St. Gellért Square & B-15 & 17.5 & 50.0 & 12 \\
\hline Móricz Zs. Square & B-14 & 13.0 & 57.7 & 8 \\
\hline Móricz Zs. Square & B-13 & 18.7 & 49.0 & 8 \\
\hline Móricz Zs. Square & B-11 & 18.0 & 46.0 & 7 \\
\hline Móricz Zs. Square & B-12 & 15.0 & 43.0 & 9 \\
\hline Móricz Zs. Square & B-25 & 16.0 & 49.0 & 13 \\
\hline Móricz Zs. Square & B-24 & 15.0 & 44.0 & 12 \\
\hline Móricz Zs. Square & B-10 & 11.0 & 48.0 & 17 \\
\hline Bocskai Street & B-9 & 12.5 & 49.5 & 16 \\
\hline Bocskai Street & B-8 & 10.0 & 48.5 & 16 \\
\hline Bocskai Street & B-7 & 14.5 & 49.5 & 8 \\
\hline Bocskai Street & B-6 & 7.5 & 38.0 & 7 \\
\hline Bocskai Street & B-5 & 15.5 & 40.0 & 6 \\
\hline Bocskai Street & B-4 & 5.5 & 40.0 & 12 \\
\hline
\end{tabular}

\begin{tabular}{|c|c|c|c|c|}
\hline \multirow{2}{*}{$\begin{array}{l}\text { Place of } \\
\text { borehole }\end{array}$} & \multirow{2}{*}{$\begin{array}{c}\text { Sign of } \\
\text { borehole }\end{array}$} & \multicolumn{2}{|c|}{$\begin{array}{c}\text { Depth of samples } \\
{[\mathrm{m}]}\end{array}$} & \multirow{2}{*}{$\begin{array}{c}\text { No. of } \\
\text { samples }\end{array}$} \\
\hline & & from & to & \\
\hline Bocskai Street & B-3 & 8.0 & 40.0 & 9 \\
\hline Bocskai Street & B903 & 10.4 & 22.1 & 4 \\
\hline Tétényi Street & B902 & 8.6 & 26.4 & 6 \\
\hline Tétényi Street & B901 & 13.1 & 27.6 & 4 \\
\hline Tétényi Street & B702 & 6.0 & 29.9 & 9 \\
\hline Tétényi Street & B703 & 6.7 & 34.8 & 13 \\
\hline Tétényi Street & B704 & 6.0 & 34.6 & 13 \\
\hline Tétényi Street & B705 & 8.0 & 34.8 & 10 \\
\hline Tétényi Street & B-55 & 6.0 & 49.0 & 27 \\
\hline Tétényi Street & B-56 & 5.8 & 47.5 & 16 \\
\hline Tétényi Street & B-57 & 6.8 & 42.0 & 18 \\
\hline Kelenföld Station & B-58 & 14.0 & 59.5 & 25 \\
\hline Kelenföld Station & B-59 & 15.2 & 55.0 & 12 \\
\hline Kelenföld Station & B-60 & 13.0 & 47.0 & 10 \\
\hline Kelenföld Station & B-61 & 7.8 & 48.0 & 16 \\
\hline Kelenföld Station & B-62 & 8.0 & 50.0 & 21 \\
\hline Kelenföld Station & B-63 & 12.0 & 45.5 & 15 \\
\hline Kelenföld Station & B706 & 8.9 & 29.6 & 10 \\
\hline Kelenföld Station & JT-901 & 15.5 & 35.0 & 6 \\
\hline Kelenföld Station & JT-902 & 9.0 & 17.0 & 2 \\
\hline Total & 41 & 5.5 & 60 & 482 \\
\hline
\end{tabular}

compressive strength $\left(\sigma_{c}\right)$. The number of samples for each parameter is listed in Table 2.

The amount of available data for each interval is different. No interval with all 17 parameters exists; however, the number of intervals with at least 15 parameters is 113. Those with at least 8 parameters number 301 (Fig. 4). There are five parameters, namely water content, plasticity limit, liquid limit, plasticity index, consistency index, which are available for all samples.

Table 2

Studied parameters and their abbreviations, no. of samples

\begin{tabular}{|l|c|c|}
\hline \multicolumn{1}{|c|}{ Type of data } & Abbreviation & $\begin{array}{c}\text { No. of } \\
\text { sample }\end{array}$ \\
\hline Water content & $\mathrm{w}[\%]$ & 454 \\
\hline Plasticity limit & $\mathrm{w}_{\mathrm{P}}[\%]$ & 471 \\
\hline Liquid limit & $\mathrm{w}_{\mathrm{L}}[\%]$ & 467 \\
\hline Plasticity index & $\mathrm{I}_{\mathrm{P}}[\%]$ & 475 \\
\hline Consistency index & $\mathrm{I}_{\mathrm{C}}[-]$ & 452 \\
\hline Wet density & $\rho_{\mathrm{w}}\left[\mathrm{kg} / \mathrm{m}^{3}\right]$ & 300 \\
\hline Dry density & $\rho_{\mathrm{d}}\left[\mathrm{kg} / \mathrm{m}^{3}\right]$ & 273 \\
\hline $\begin{array}{l}\text { Water-saturated } \\
\text { density }\end{array}$ & $\rho_{\mathrm{s}}\left[\mathrm{kg} / \mathrm{m}^{3}\right]$ & 247 \\
\hline
\end{tabular}

\begin{tabular}{|l|c|c|}
\hline \multicolumn{1}{|c|}{ Type of data } & Abbreviation & $\begin{array}{c}\text { No. of } \\
\text { sample }\end{array}$ \\
\hline Void ratio & $\mathrm{e}[-]$ & 250 \\
\hline Porosity & $\mathrm{n}[\%]$ & 250 \\
\hline Ratio of solid particles & $\mathrm{s}[\%]$ & 250 \\
\hline Degree of saturation & $\mathrm{S}_{\mathrm{r}}[-]$ & 209 \\
\hline Cohesion & $\mathrm{c}\left[\mathrm{kN} / \mathrm{m}^{2}\right]$ & 149 \\
\hline Angle of friction & $\varphi\left[{ }^{\circ}\right]$ & 144 \\
\hline $\begin{array}{l}\text { Coefficient of } \\
\text { compressibility }\end{array}$ & $\mathrm{E}_{\mathrm{S}}\left[\mathrm{MN} / \mathrm{m}^{2}\right]$ & 17 \\
\hline Modulus of elasticity & $\mathrm{E}[\mathrm{MPa}]$ & 44 \\
\hline Compressive strength & $\sigma_{\mathrm{c}}[\mathrm{MPa}]$ & 226 \\
\hline
\end{tabular}




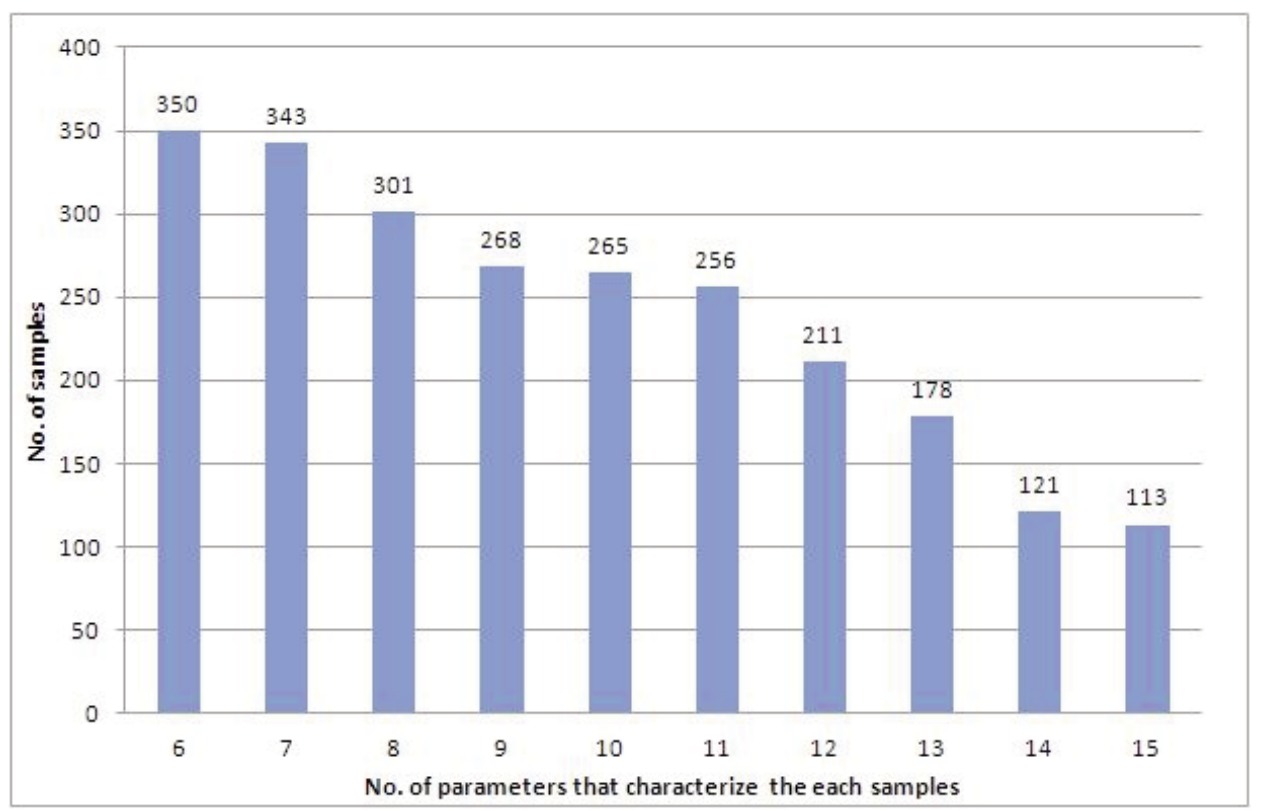

Fig. 4

Distribution of number of available physical parameters

\section{Methods}

Descriptive statistics was used to analyze and systematize the data set. After data gathering, items were plotted, grouped, categorized and characterized with basic statistical parameters such as minimum, maximum, mean, median, mode, range, standard deviation, coefficient of variation, skewness and kurtosis.

A frequency diagram of every soil-physical characteristic was defined, which represents the frequency belonging to different variables. Histograms help filtration of outside values because these occur between the higher and the lower values; their frequency is low. Non-sampling errors caused by bad data recording and/or measurement error are independent of data distribution and can therefore be eliminated. The dataset of over 4700 values was cleaned of outside values.

The frequency diagram is suitable for displaying the normal distribution of variables; it can help determine by on the face of it. Fit analysis of the empirical distribution was made using the Kolmogorov-Smirnov test (with the SPSS Statistics 17.0 software). This test is based on the maximal absolute difference between the normal and the empirical distribution function, which becomes sensitive through a correction factor upon the number of elements. The test function is the following equation, and the null hypothesis means that the empirical distribution is a normal one. 


$$
z=\left|F_{\text {emp }}-F_{\text {norm }}\right| \times \sqrt{N}
$$

It is worthwhile displaying connections between parameters through graphical representation before using mathematical methods, which demand more calculation. Parameter pairs were illustrated on scatter plots and regression curves were fitted on these points using the least-squares method. The strength of the relationship was characterized by the square of Pearson's correlation coefficient (R2), such as a real measure. This analysis was made with MS Excel software.

\section{Results}

\section{Geostatistical characteristics}

Frequency histograms of every geotechnical parameter (Figs $5 a, 5 b$ ) were made using statistical software (SPSS Statistics 17.0). Since numerous discrete data were available, it was categorized in $\mathrm{k}$ classes, calculated with the following formula ( $\mathrm{n}$ being the number of samples):

$$
\mathrm{k}=1+3.3^{*} \lg \mathrm{n}
$$

Conjectures obtained by graphical representation were proved by the Kolmogorov-Smirnov test. With this test the following parameters come from a normal distribution on a 5\% significance level: liquid limit, wet, dry and saturated density, void ratio, porosity, ratio of solid particles, cohesion, angle of friction, coefficient of compressibility and modulus of elasticity. However, the other variables are used because of a sufficiently large available sample size.

The statistical characteristics of soil-mechanics variables - such as mean, median, range, standard deviation, variance, skewness - are shown in Table 3. The water content is between 4 and $23 \%$, the plasticity limit is from 15 to $31 \%$ and the liquid limit lies between 27.7 and $85.6 \%$. More than half of samples have a plasticity index above $30 \%$; therefore they are considered to be fat clay. The minimum of the consistency index is 1.00 and its maximum is 2.0; thus samples were classified as very stiff clay. The geologic process of the genesis of the Kiscell Clay explains this.

Wet density is between 1960 and $2510 \mathrm{~kg} / \mathrm{m}^{3}$. The $2510 \mathrm{~kg} / \mathrm{m}^{3}$ value is also the upper limit of saturated density, which is explained by the presence of many totally saturated samples. The mode of its distribution is 1.0 and more than $80 \%$ of the samples have a degree of saturation above 0.7. This is also seen on the histogram. Void ratio takes up values between 0.13 and 0.68 , with a median of 0.37 .

Values of cohesion, angle of friction, coefficient of compressibility, modulus of elasticity and compressive strength cover a wide range, and have wide standard deviations. Their interpretation indicates that these parameters are very sensitive to the laboratory testing process. Furthermore, the origin of the samples is not the

Fig. $5 \mathrm{a} \rightarrow$

Histogram of soil-physical parameters (part 1) 
Engineering geologic evaluation of overcompacted claystone, new metro line, Budapest 231
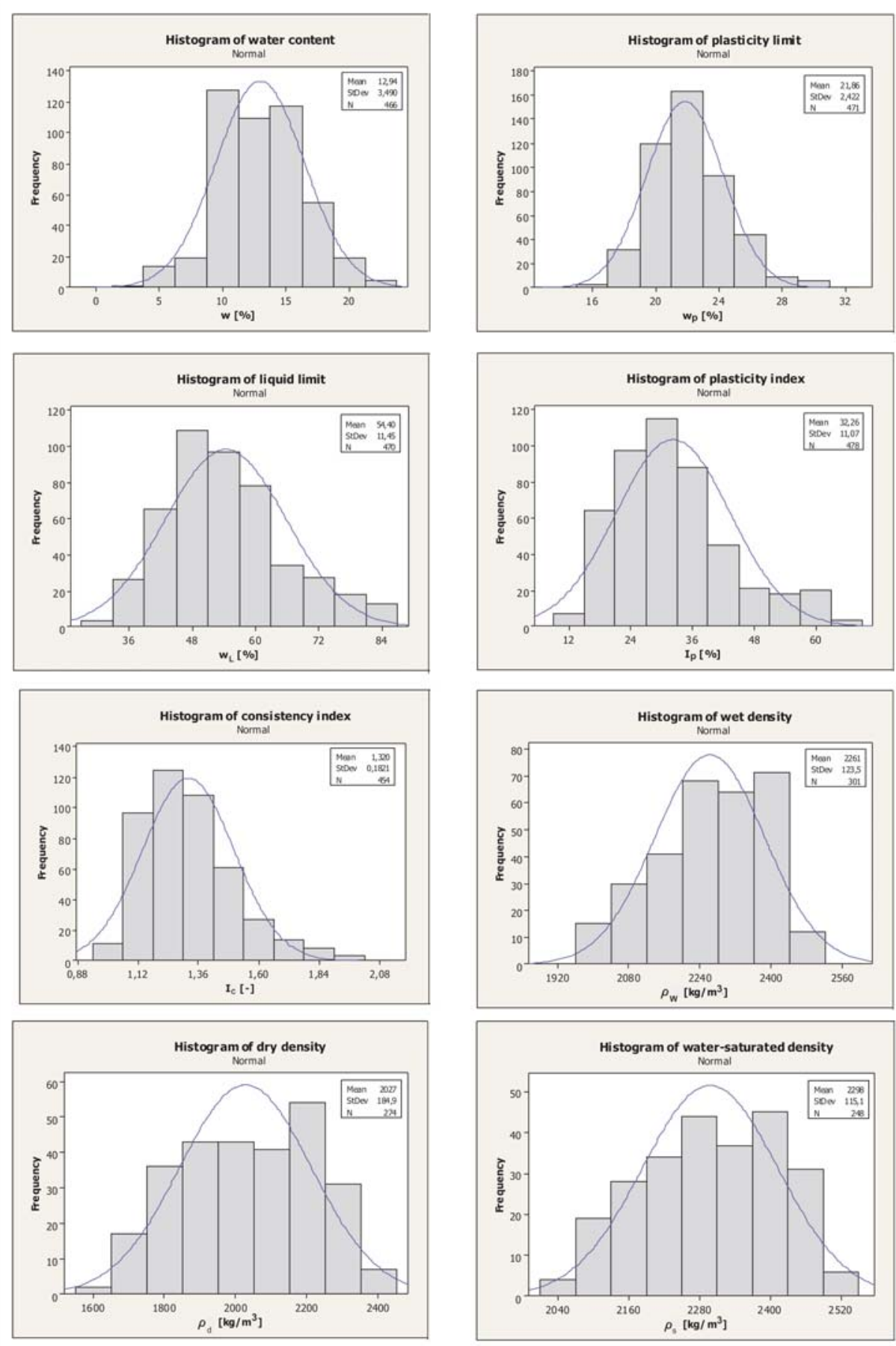

Central European Geology 55, 2012 

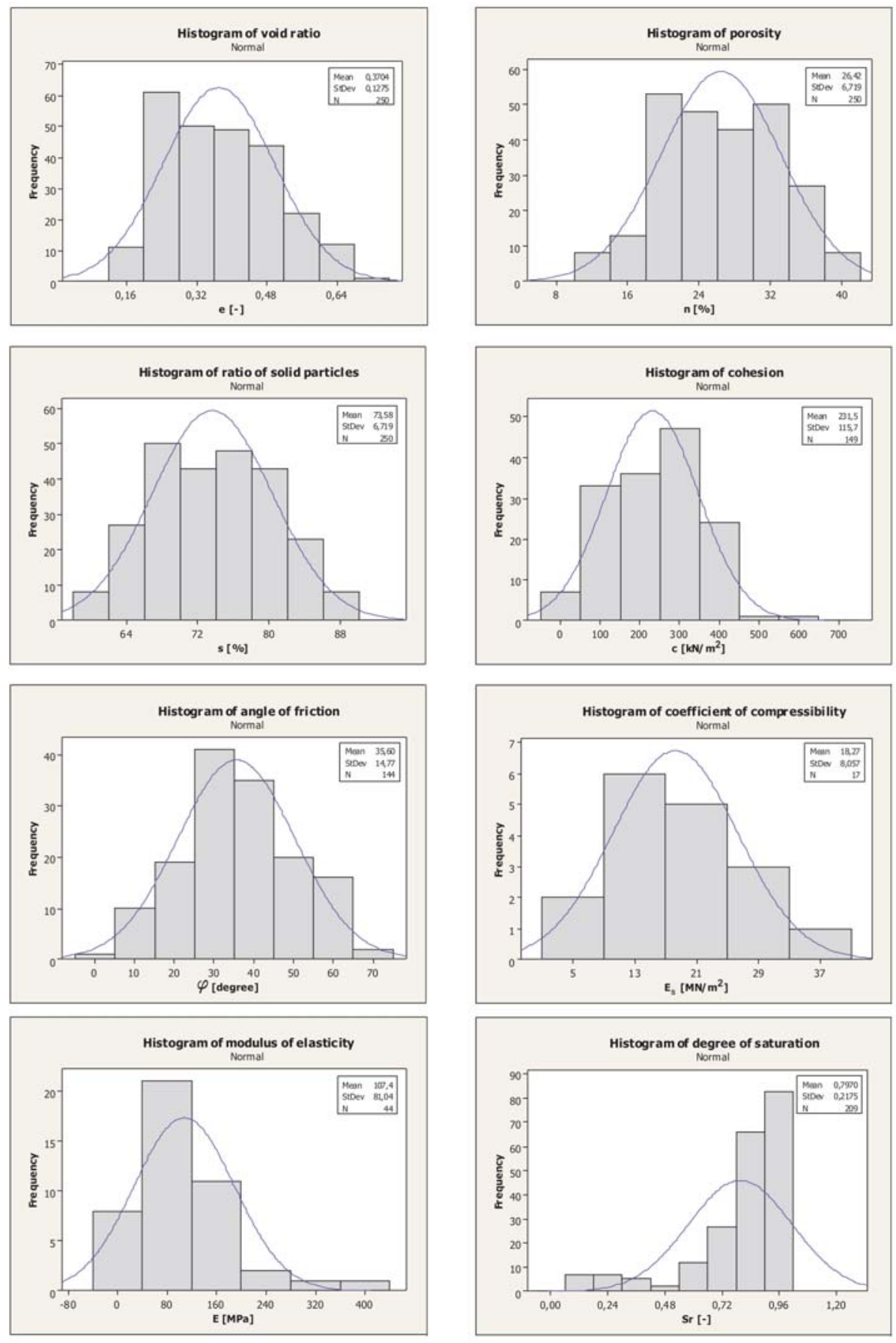

Central European Geology 55, 2012 


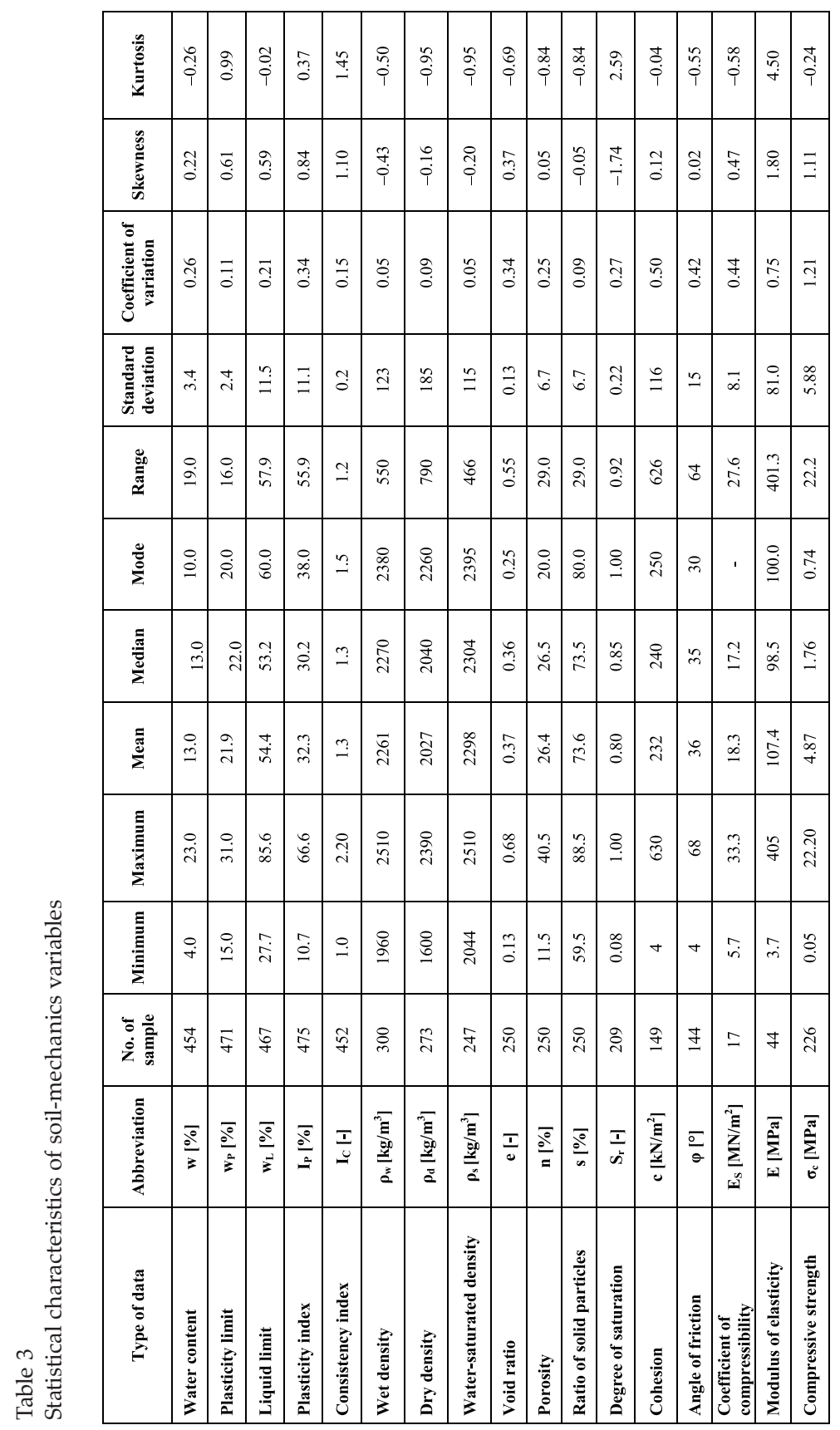


same; consequently it is necessary to build some additional category for these samples. The basis of this additional categorization could be the different zones, for example expanded, cracked and rocklike Kiscell Clay, classified by void ratio or compressive strength values.

Skewness and kurtosis of distribution were analyzed. Skewness is a measure of symmetry, negative skew indicates that the tail on the left side of the distribution is longer than on the right side. Consistency index, degree of saturation, compressive strength and modulus of elasticity show greater dissymmetry. Kurtosis is a measure of whether the data are peaked (positive value) or flat (negative value) relative to a normal distribution. Saturation and modulus of elasticity have a greater degree of peakedness, which means that the mode is typical of many samples.

\section{Correlation of engineering geologic parameters}

To begin with the relationships between depth and other parameters are illustrated. The point pairs of depth and wet density are plotted in Fig. 6 . The regression function is exponential; its inverse equation is as follows $\left(\rho_{\mathrm{w}}\right.$ in $\left[\mathrm{kg} / \mathrm{m}^{3}\right]$, depth in $\left.[\mathrm{m}]\right)$

$$
\rho_{w}=333.3 \ln (37.3 \times \text { depth })
$$

The function shows that wet density increases with growth of depth but that the gradient increases, and that the change of density decreases with increasing depth. Correlation is relatively strong between variables; the square of the correlation coefficient is 0.58 .

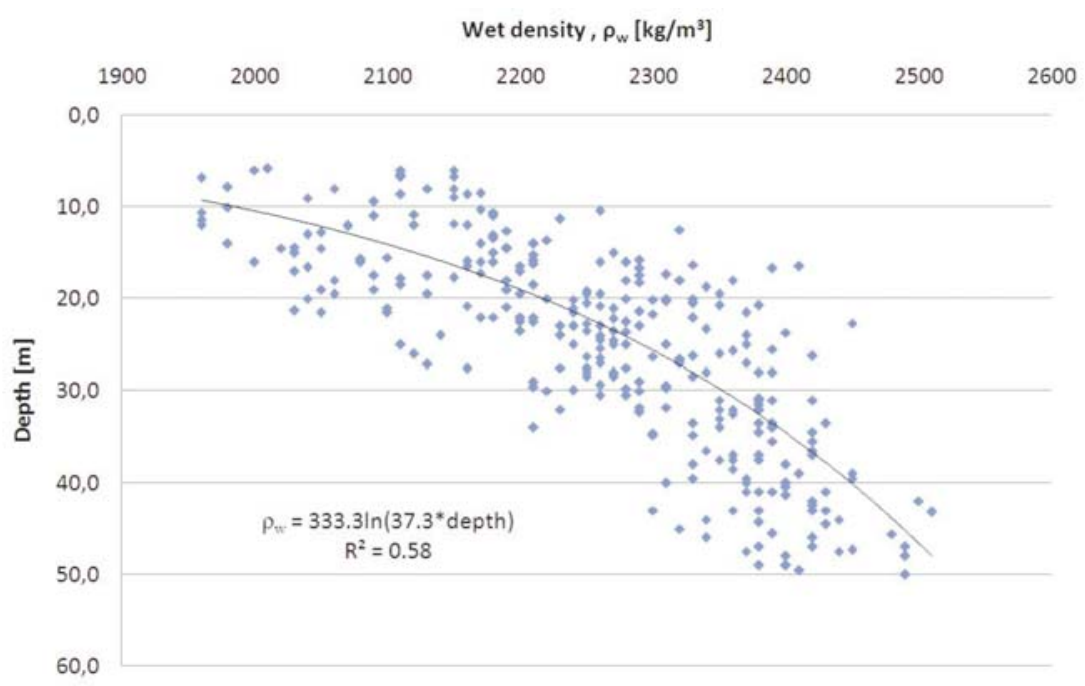

Fig. 6

Relationship between depth and wet density 
Figure 7 shows the connection between depth and void ratio. The best fitted curve $\left(R^{2}=0.59\right)$ is a power function inverse equation, which is (depth in $[\mathrm{m}]$ ):

$$
e=\left(\frac{\text { depth }}{7.34}\right)^{-0.94}
$$

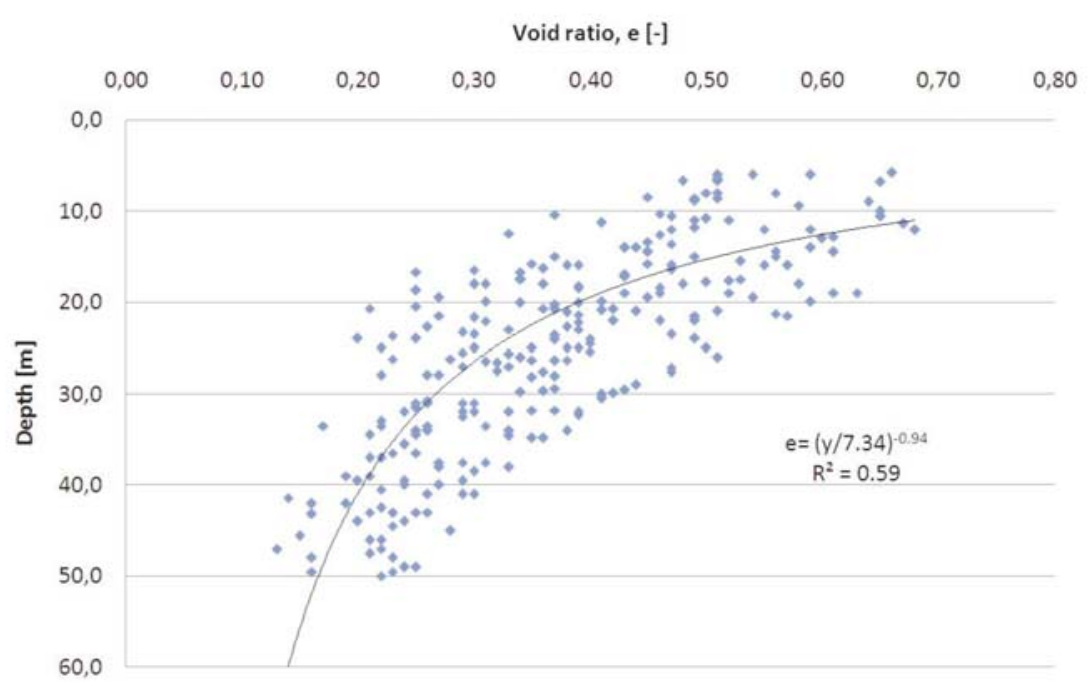

Fig. 7

Relationship between depth and void ratio

The variables change in opposing directions and the function gradient decreases with the increase of void ratio.

Water content also is related to wet density and void ratio (Figs 8 and 9). The relationships can be characterized with linear function estimated equations, which are:

$$
\begin{gathered}
w=0.0214 \times \rho_{w}+61.7 \\
w=21.5 \times e+5.3
\end{gathered}
$$

Wet density and void ratio affect depth and water content in opposite directions. Therefore the deeper the sample comes from, the higher the wet density and the lower void ratio it has, and the higher the water content is, the lower the wet density and the higher the void ratio of the sample. Accordingly wet density and void ratio are connected to one another (Fig. 10), and this relationship is strong $\left(R^{2}=0.93\right)$ and negative.

$$
\rho_{w}=-973 \times e+2628
$$




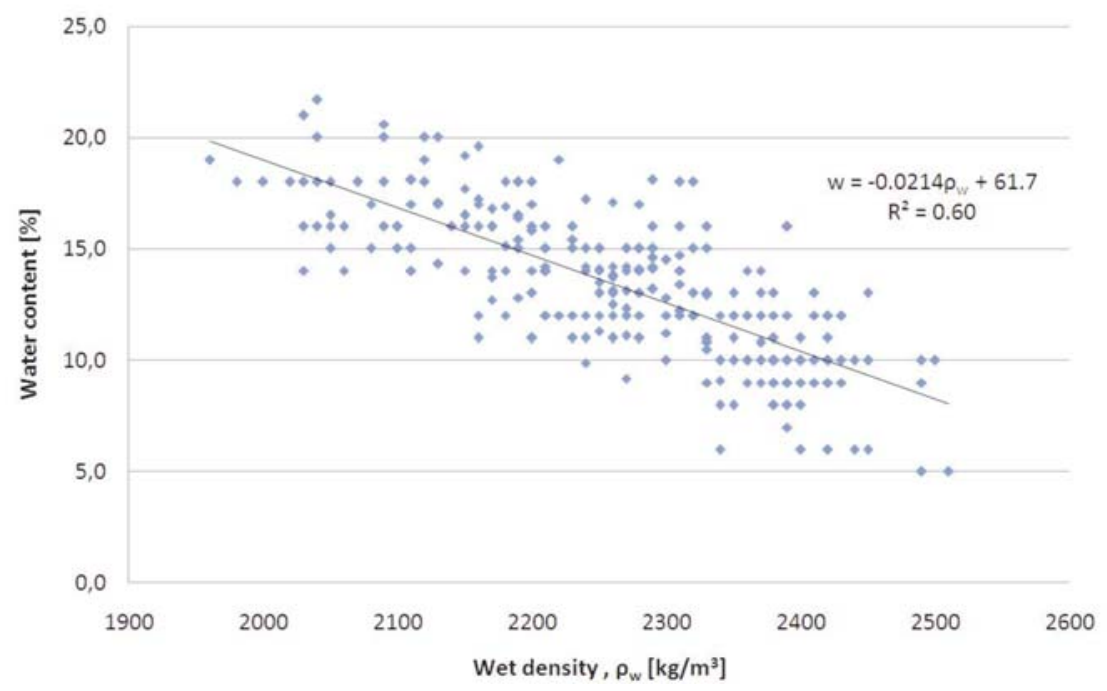

Fig. 8

Relationship between water content and wet density

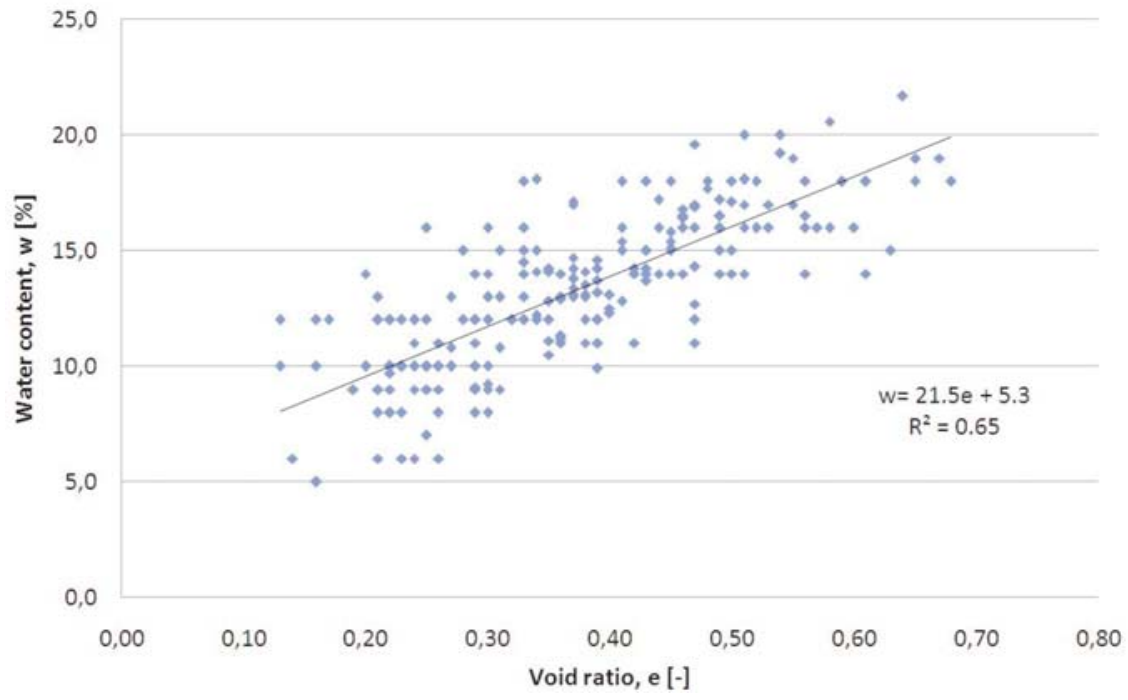

Fig. 9

Relationship between water content and void ratio 


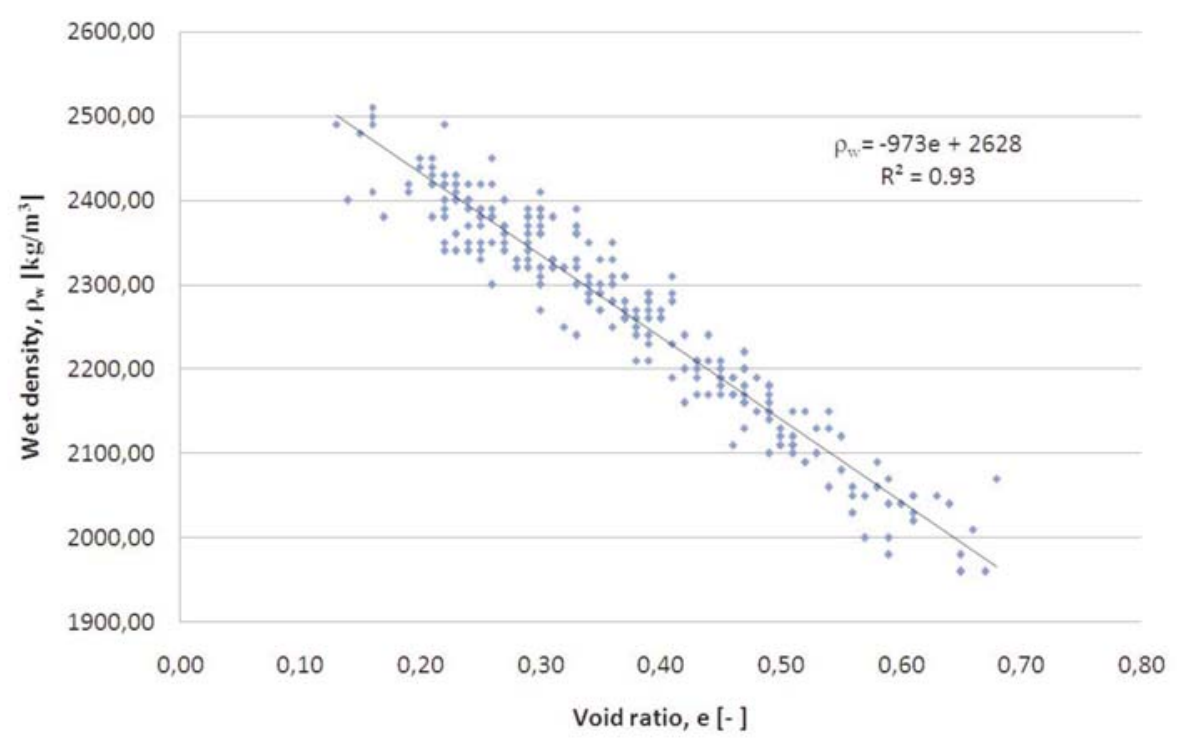

Fig. 10

Relationship between wet density and void ratio

Between the different densities a strong linear connection can be noticed (Fig. 11). The coefficients of determination are 0.92 and 0.99 . The regression functions are:

$$
\begin{aligned}
& \rho_{w}=0.68 \rho_{d}+873 \\
& \rho_{s}=0.63 \rho_{d}+1007
\end{aligned}
$$

The water saturated state can be demonstrated withal line describing the relation between dry and theoretically saturated. Saturated density is obtained in the following way:

$$
\rho_{s}=\rho_{d}+\frac{e}{e+1} \rho_{\text {water }}
$$

The line that plots the connection between wet and dry density is steeper than that of the function of dry and saturated, so the higher the dry density values are, the closer wet density values are denoted by saturated density values. This correlates with the above-mentioned relationship between density and void ratio, indicating that the Kiscell Clay has a high average degree of saturation (0.85).

Finally the plasticity diagram was also plotted (Fig. 12) with the A-line of Casagrande. The connection between plasticity index and liquid limit was described by a linear equation with a high correlation value $\left(R^{2}=0.95\right)$.

$$
I_{p}=0.93\left(w_{L}-17.6\right)
$$

The values are located above A-line; therefore their origin is not organic. 


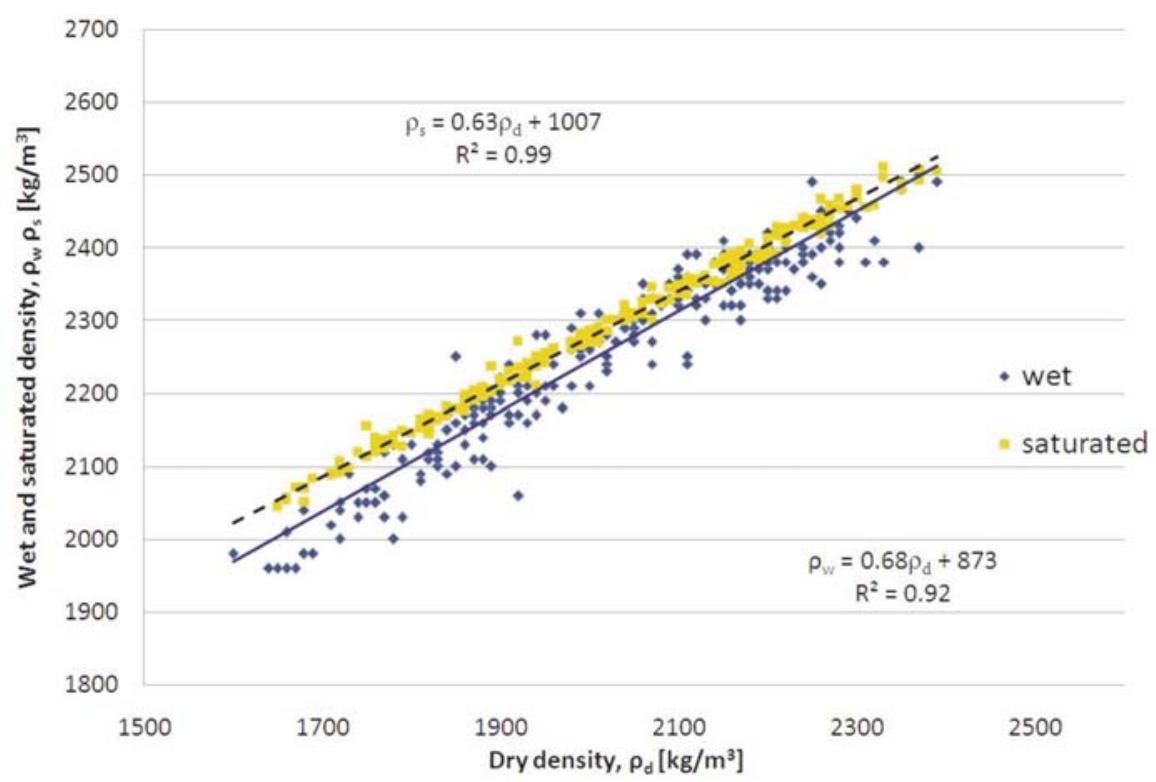

Fig. 11

Relationship between different densities (wet, dry, water-saturated)

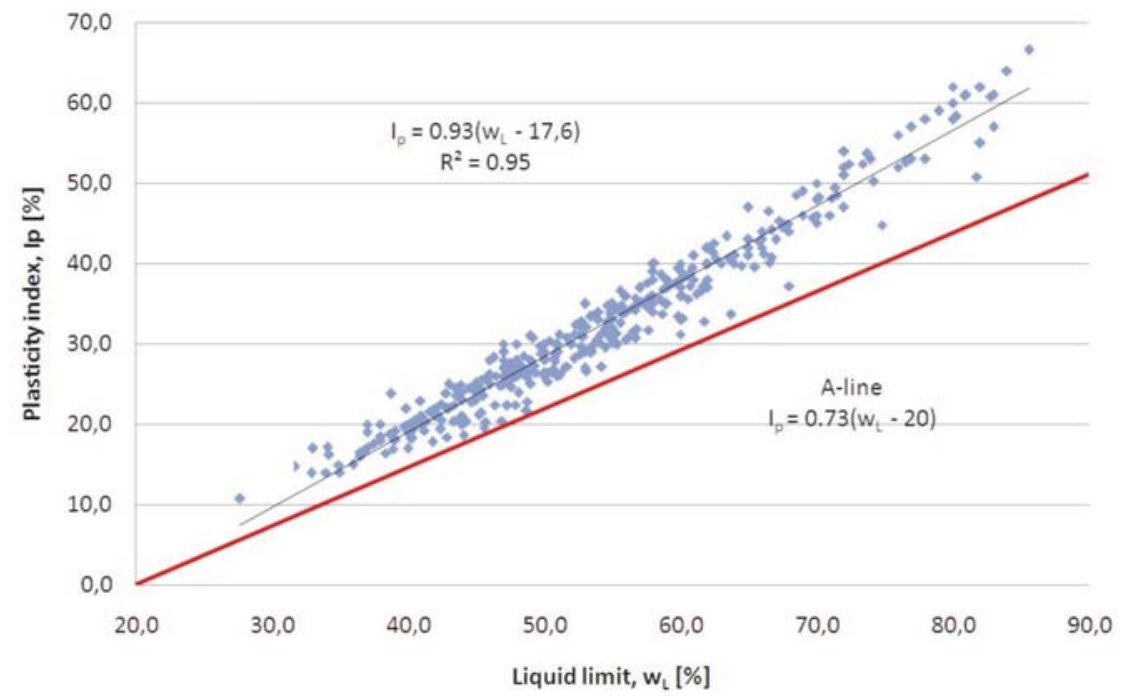

Fig. 12

Relationship between plasticity index and liquid limit (plasticity diagram with A-line) 


\section{Discussions}

The application of an engineering-geologic evaluation of geotechnical data sets is becoming increasingly common (Erguler and Ulusay 2009). The reason for this is that it is usually not easy to perform the investigations; the most important parameters, such ass cohesion and angle of friction, are very difficult to measure (Goktepe et al. 2008). The statistical evaluation of previous field information can provide useful results for new engineering-geologic (or geotechnical) projects. Due to engineering requirements, geostatistical methods also help in optimizing data sets (Marache et al. 2009).

The geostatistical parameters of previous data can be used to identify the different geologic units, and graphically plot them as engineering-geologic maps (Marache et al. 2009). This is useful when the investigated area has a more complex geology. The thickness of clay layers were investigated statistically by Salman et al. (2009).

When the investigated area consist of one main geological unit, the geostatistical analyses are very useful in terms of estimating the geotechnical parameters of this unit (Görög 2007a). However, our research has found that there are parameters that can be correlated (e.g. depth and wet density; Fig. 6) while others such as compressive strength and density show less of a relationship. These results indicate that further statistical evaluation is needed and three-function analyses might provide better results.

\section{Conclusions}

Based on the data set of 4700 engineering-geologic parameters from 41 cores, water content, liquid limit, plasticity index, densities, void ratio and degree of saturation show a lower standard deviation.

The water content varies between 4 and $23 \%$, since more than half of the studied clays belong to high plasticity clays.

The water-saturated density is between 1960 and $2150 \mathrm{~kg} / \mathrm{m}^{3}$, which is in good agreement with the high degree of saturation ( 0.85 on average).

Cohesion, coefficient of compressibility, modulus of elasticity and compressive strength show relatively high standard deviations. These differences can be related to the differences in laboratory test conditions, namely that these parameters are very sensitive to test conditions. Another explanation is the minor differences in lithology.

A clear correlation was found between depth and wet density. The void ratio is found to be inversely influenced by depth, with an exponential function.

The relationships between the densities (dry, wet and water-saturated) indicate that with an increase in dry density the difference between the wet and watersaturated densities gradually diminish.

The present study demonstrated that the engineering-geologic evaluation of clayey formations is possible using a large set of engineering-geologic data in combination with geostatistics. 
Since most of these physical properties are used as input parameters in engineering-geologic modeling it is necessary to use these data sets with care, by understanding the major trends. It is important to note that further laboratory analyses are required for each construction site.

\section{Acknowledgement}

The work reported in this paper was developed within the framework of the "Talent care and cultivation in the scientific workshops of the BME" project, grant TÁMOP-4.2.2.B-10/1--2010-0009.

\section{References}

Erguler, Z.A., R. Ulusay 2009: Assessment of physical disintegration characteristics of clay-bearing rocks: Disintegration index test and a new durability classification chart. - Eng. Geol., 105, pp. 11-19.

Farkas, J., M. Müller, Gy. Horváth, B. Móczár, J. Pusztai, V. Bíró 1999: Representative subsoil condition of Budapest from observations of the longest linear excavation to date.- Közúti és Mélyépítési Szemle, 49, 5, 199-207.

Geovil Kft. 2005: Budapest 4. metróvonal, I. szakasz, Összefoglaló mérnökgeológiai, hidrogeológiai és geotechnikai szakvélemény, "B" kötet, Budai oldal. (Budapest Metro line no 4, Section I., Engineering geological, hydrogeological and geotechnical summary report, "B" volume, Buda side).

Goktepe, A.B, S. Altunb, G. Altintasc, O. Tand 2008: Shear strength estimation of plastic clays with statistical and neural approaches. - Building and Environment 43, pp. 849-860.

Görög, P. 2007a: A kiscelli agyag fizikai jellemzőinek statisztikai vizsgálata (Statistical analyses of the physical properties of Kiscell Clay). - Mélyépítés, 2007/4, pp. 18-25.

Görög, P. 2007b: Engineering geologic properties of the Oligocene Kiscell Clay. - Central European Geology, 50/4, pp. 313-329.

Hegyi, J., E.Z. Kiss, P. Szlabóczky 1981: Általános földtani eredmények a budapesti metróvonalak földtani kutatásaiból (Geological results of geological explorations of the metro lines in Budapest). - Általános Földtani Szemle, 16, pp. 5-24. (In Hungarian)

Horváth, T., M. Fáy, Cs. Sándor 2000: A metróvonal mérnökgeológiai adottságai (Engineering geological setting of the Metro Line). - Földtani Kutatás, 37, 2, pp. 35-44.

Marache, A., D. Breysse, C. Piette, P. Thierry 2009: Geotechnical modeling at the city scale using statistical and geostatistical tools: The Pessac case (France). - Eng. Geol., 107, pp. 67-76.

Németh, G. 1980: Az Újlaki III. bánya Jablonka úti szakaszán bekövetkezett felszínmozgás vizsgálata (Analysis of the landslide in Jablonka Street area of Újlak III. clay pit). - Mélyépítés tudományi szemle, 30, 5, pp. 195-206.

Paál, T. 1976: A budai agyagok mérnökgeológiai összehasonlítása matematikai statisztikai alapon (Engineering geological comparison of clays in Buda based on statistics). - Földtani Közlöny, 106, pp. 229-256

Paál T. 2001: Geológiai megfigyelések az EUROCENTER-Óbuda áruház építése kapcsán (Geological observation during the construction of EUROCENTER-Óbuda department store). - Földtani Közlöny, 131, 3-4, pp. 569-579.

Salman, A., K. Ibrahim, G. Saffarini, M. Al-Qinna 2009: Geostatistical calculation for clay reserve in Azraq Basin in Jordan. - Journal of Geography and Regional Planning, 2/5, pp. 144-153.

Tóth T., T. Bozsó, T. Horváth 2003: Sziklafalak a Dunában (Rock cliffs in Danube). - Mélyépítés, I/4, pp. 16-23.

www1: www.metros.hu

www2: www.metro4.hu 